\title{
The Difference in Level of Cardiorespiration Endurance in Student of SMAN Based on the Geographic Location of Population Settlements in Kepahiang
}

\author{
Yulva Andresta ${ }^{1, *}$ Suharjana Suharjana ${ }^{1}$
}

\author{
${ }^{1}$ Universitas Negeri Yogyakarta, Indonesia \\ ${ }^{*}$ Corresponding author.Email: yulvaandresta.2020@student.uny.ac.id
}

\begin{abstract}
This study aimed to determine whether or not there are differences in cardiorespiratory endurance between students living in highland areas and students living in lowland areas. This study used a quantitative descriptive research with a survey method that compares 2 sample groups that have different geographical locations. Sampling in this study used cluster sampling technique with 2 stages, thus the number taken was $15 \%$ of the population, so the number of samples taken was 24 students from each school. To find out the difference between the two groups, each group was given a Multistage Fitness Test (MFT). In the test, the results obtained from the analysis of normality data in the highland area Lo $=0.1<$ Ltable $=0.173$ which means the data was normally distributed and the lowland area Lo $=0.138<0.173$ which means the data was also normally distributed. Homogeneity test Fcount $=1.5329<$ Ftable $=1.9838$ which means both variances were homogeneous and the $t$ test was obtained $T_{-}$count (3.65) > T_table (1.679). Thus, the hypothesis $\mathrm{Ha}$ was accepted, so that there was a significant difference between the cardiorespiratory endurance of students living in highland areas and students living in lowland areas. The difference was $13.32 \%$. Thus, it could be concluded that the cardiorespiratory endurance of students in highland areas was better than students in lowland areas.
\end{abstract}

Keywords: Endurance, V02Max, Geographical Location.

\section{INTRODUCTION}

According to Sudirjo and Alif [1] physical education is a learning process through physical activities that designed to improve physical fitness, develop motor skills, knowledge and behavior of healthy and active living, sportif, and emotional intelligence.

With physical education, students will get various good benefits such as having good physical fitness, healthy living habits and having knowledge and understanding of human movements. In order to be able to carry out tasks and daily physical activities well, it is necessary to have the quality of the ability to the function of the body's organs in accordance with the demands of the task of movement from the activities that it undergoes.

Physical fitness is a person's initial capital to carry out daily physical activities effectively and efficiently. It is supported by the opinion Apriani and Nirwana [2], they stated that by having good physical fitness, daily activities will feel relaxed without heavy fatigue.

For students, physical fitness is very important to maintain physical condition while studying at school and outside of school, and with good physical fitness, it is hoped that students can learn to be more passionate, enthusiastic, not susceptible to disease, not easily tired, creative and innovative, so that they can achieve optimally and face challenges both in the school environment and in the community. Therefore, in the world of education, physical fitness is very important, thus physical fitness is included in a curriculum in the subjects of Physical Education, Health and Sports (PJOK). With good physical fitness, students are expected to have a fit body so that they can improve their human resources and become excellent human beings. 
According to Sukmati [3], there are two types of physical fitness, namely Health related fitness and Skill related fitness. Physical fitness related to health includes heart and lung endurance, muscle endurance, muscle strength, flexibility, and body composition. Based on those several components of physical fitness, cardiorespiratory or cardiovascular endurance is the biggest contributor in improving and maintaining fitness or good health.

According to Suharjana [4] Cardiorespiratory is the main capital for physical fitness and it is even considered synonymous with physical fitness, so that by knowing the level of cardiorespiratory fitness will also show the level of physical fitness.

Cardiorespiratory fitness is influenced by several factors, as stated by Suharjana [4] that physiological factors that affect cardiorespiratory endurance are: heredity (genetic), age, gender, and physical activity. Geographical location of an area is also a factor in a person's level of physical fitness, population activities in an area are strongly influenced by geographical conditions, especially physical conditions.

One of them is in terms of the topography of the region. Topography is the study of the shape of the earth's surface and other objects such as planets, natural satellites and asteroids. In that case, topography can also be defined as the relief or shape of the earth's surface. [5]

Natural topography is the dominant part that the difference could be seen between one area and another, for example, highland and lowland areas. According to Molenaar [6] the height of the residence according to the geographical location with climatic characteristics has a major influence on body shape. People who live in the highlands have larger chest and lung circles than people in the lowlands. Thus, the degree of lung function in the population living in the highlands is greater than in the population living in the lowlands. Highlands are plains located at an altitude above 700 meters above sea level. The lowlands have a climate that is not too cold and has an altitude of 0-500 meters above sea level.

In this study, researcher used high school which has a different geographical location. Namely schools in the lowlands and schools in the highlands. In accordance with the results of these observations, the researcher wanted to conduct research on the Cardiorespiratory Endurance Level (VO2 Max) in high school students based on the geographical location of the school in Kepahiang Regency. This research is entitled "The Differences in Cardiorespiratory Endurance Levels in High School
Students Based on the Geographical Location of Population Settlements in Kepahiang Regency"

\section{METHODS}

This type of research is a quantitative descriptive field research. The method used in this study is a survey method. To describe the findings of this study, researcher needed data to analyzed, therefore data was collected using the Multistage Fitness (MFT) test instrument.This study aimed to determine the differences in the level of cardiorespiratory endurance in high school students based on the geographical location of residential areas in Kepahiang Regency.

In this study, the researcher used 2 populations, namely the high school population in the highlands and the school population in the lowlands. In this research, the sampling technique was cluster sampling. Regional sampling technique was used to determine the sample if the object to be studied or the data source is very broad.

In this study, the regional sampling technique was carried out in 2 stages. The first stage is looking for schools that will be sampled in the highlands and lowland areas and the second stage is to determine students who will be randomly sampled from schools that have been chosen at random in stage one. Sampling in the second stage was taken as much as $15 \%$ of male students in each school. Thus the total sample of highland and lowland students was 24 students and a total of 48 students.

Techniques in collecting data used tests, to determine the level of cardiorespiratory endurance of high school students based on residential areas in Kepahiang Regency, the researcher used the Multistage Fitness (MFT) instrument. With a validity value of 0.88.[7]

The data analysis technique in this research was used descriptive quantitative statistical techniques with percentages. Descriptive statistical techniques are statistics that can be used when the researcher only wants to describe the sample data, and does not want to make conclusions that apply to the population in which the sample is taken. [8]

To describe the level of students' cardiorespiratory endurance, the test results are first converted to the table for the multistage fitness test norm as follows: 
Table 1. Norma $\mathrm{v}_{2}$ max multistage fitness test age 13-19 years old [9]

\begin{tabular}{|c|c|c|}
\hline Male & Female & Category Freshness \\
\hline$>51.0$ & $>39.0$ & Very Good \\
\hline $45.2-50.9$ & $35.0-38.9$ & Good \\
\hline $38.4-45.1$ & $31.0-34.9$ & Medium \\
\hline $35.0-38.3$ & $25.0-30.9$ & Less \\
\hline$<35.0$ & $<25.0$ & Very Less \\
\hline
\end{tabular}

Before the collected data was analyzed using ttest to determine the hypothesis, it is necessary to know whether the data is normally distributed or not. In addition, it must also be known whether the two groups are homogeneous or not.

The normality test is used to process the data in determining whether the high school students who have been tested are normally distributed or not. If the data is normally distributed, then the statistics used are parametric statistics. Otherwise, if the data is not normally distributed, the statistics used are nonparametric statistics. Therefore, before the test is carried out, the data normality test will be carried out first by using the Lilliefors formula.

$$
Z_{i}=\frac{X_{i}-\bar{X}}{s}
$$

If it is known that the data is normally distributed, then the next step is to test the homogeneity of variance with the formula F. Sugiyono [8] stated that before the analysis of variance is used for hypothesis testing, it is necessary to test the homogeneity of variance first. The homogeneity test of variance was carried out with the $\mathrm{F}$ test formula. The variance of the two data groups can be declared homogeneous if the calculated $\mathrm{F}$ value is smaller than the $\mathrm{F}$ table.

$$
F=\frac{\text { Varian terbesar }}{\text { varian terkecil }}
$$

The next step is hypothesis testing, a method for analyzing data with independent $\mathrm{T}$ tests. Independent $\mathrm{T}$ test is a comparative test or different test to find out whether there is a significant difference in mean between 2 independent groups with interval/ratio data scale.

$$
t=\frac{\bar{x}_{1}-\bar{x}_{2}}{\sqrt{\frac{\left(n_{1}-1\right) \cdot s_{1}{ }^{2}+\left(n_{2}-1\right) s_{2}{ }^{2}}{n_{1}+n_{2}-2}\left(\frac{1}{n_{1}}+\frac{1}{n_{2}}\right)}}
$$

\section{RESULT AND DISCUSSION}

\subsection{Results}

Based on the data obtained during the study, the results are as follows:

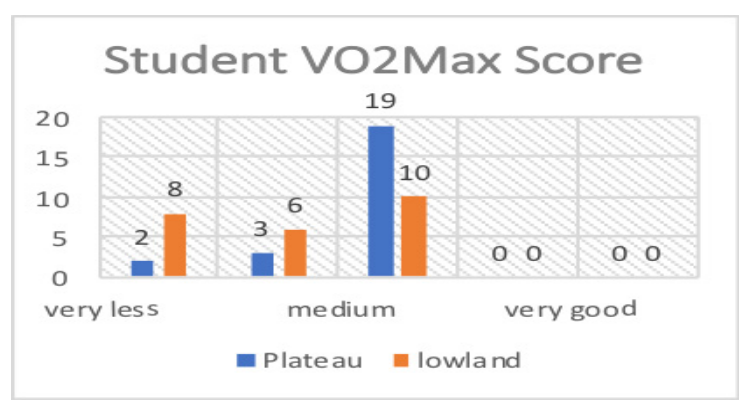

Figure 1 V0_2Max curve diagram

Based on the diagram above, it could be seen that there were several differences in the VO_2Max values achieved by students in the highlands (SMAN 4 Kepahiang) which had a classification of VO 2Max values they were, very poor were 2 people, poor were 3 people, moderate were 19 people, good was 0 , and very good was 0 . Meanwhile, students in the lowland area (SMAN 2 Kepahiang) had a classification of VO_2Max values were, very poor 8 people, poor were 6 people, moderate were 10 people, good was 0 , and very good 0 . Thus, it was known that the group of students in the highlands had an average $\mathrm{VO}_{2}$ 2Max value of 40.35. Meanwhile, for groups of students who are in lowland areas have VO_2Max with an average of 37.08 .

There was a difference between students in the highlands and students in the lowlands. The difference was in the average value of VO_2Max. Even though from the table data, it could be seen the differences, but it needed to do t-test. The t-test was to determine whether there was a difference between the two sample groups. However, before conducting the t-test, the researcher needed to test the normality and homogeneity of the data first.

Normality test of data with lilliefors formula on students who live in highland areas, namely, Lo $=0.1$ $<\mathrm{Lt}=0.173$ So it could be said that the data was normally distributed. Meanwhile, for groups of students who live in low-lying areas have Lo $=0.138$ $<\mathrm{Lt}=0.173$, it could be concluded that the data was also normally distributed.

The homogeneity of variance test was carried out on the two groups. Data were analyzed using the $\mathrm{F}$ test, with a significant level $=0.05$. The results of the $\mathrm{F}$ test were known that the calculated $\mathrm{F}$ value $=$ 
$1.5329<\mathrm{F}$ table $=1.9838$. Thus it could be said that the two variants were homogeneous.

The next step was to test the hypothesis. The method to analyze the data used independent $\mathrm{T}$ test. The independent test is a comparative test or different test to find out whether there is a significant difference or mean between 2 independent groups that display data/ratio intervals. In the t test between students who live in highland areas and in lowland areas the results were $\mathrm{t}$ count $=3.65>\mathrm{t}$ table $=1.679$, thus the hypothesis was accepted. There were a significant difference between students living in highland areas and students living in lowland areas.

\subsection{Discussion}

The results of this study indicate that students who live in highland areas have a higher level of cardiorespiratory endurance than students who live in lowland areas. It could happen because of the differences in the daily activities carried out by the students who were in highland areas and lowland areas. But, it is not only physical activity, there are many other factors that can cause differences in the level of cardiorespiratory endurance in students in highland and lowland areas. For example, the oxygen levels are different between highland areas and lowland areas.

In the highlands the oxygen content $(\mathrm{O} 2)$ and the pressure is smaller than in the lowlands. It causes the work of the heart, lungs, and blood vessels to be heavier compared to higher oxygen levels [10]. It is like students who live in highland areas that have lower oxygen levels, they have a heavier work function of the heart, lungs, and blood vessels in the band of students who live in lowland areas that have more oxygen levels.

In general, the lung volume capacity of a person who lives in a highland area is greater than the lung volume capacity of a person who lives in a lowland area, it causes the degree of lung function in the population living in the highlands is greater than in the population living in the lowlands [11]. It is not only lung volume capacity, blood hemoglobin levels of students in the highlands are greater than those in the lowlands that can bind more oxygen than in lowland areas which have lower hemoglobin levels [12].

It has been proven by the existence of this study by collecting data through tests, then the data was processed with a statistical formula whose results stated that there was a significant difference between the level of cardiorespiratory endurance of students living in highland areas and students living in lowland areas.

Students of SMAN 4 Kepahiang who live in highland areas have better level of cardiorespiratory endurance than students of SMA N 2 Kepahiang who live in lowland areas. SMA N 4 Kepahiang is in the medium category, while the students of SMA N 2 Kepahiang who live in lowland areas are in the poor category.

The results of this study were also corroborated by the opinion [6], which stated that the height of the residence according to geographical location with climatic characteristics has a major influence on body shape. Which people who live in the highlands have larger chest and lung circles than people in the lowlands. Thus, the degree of lung function in the population living in the highlands is greater than in the population living in the lowlands.

\section{CONCLUSION}

Based on the results of the research that carried out, it could be concluded that differences in geographic location could affect a person's cardiorespiratory endurance. it was proved by the results of a significant difference between the level of cardiorespiratory endurance of high school students based on the geographical location of population settlements in Kepahiang district. For high school students in highland areas, the VO2 Max value is in the medium category, while students in lowland areas are in the less category. So that the cardiorespiratory endurance of SMA N 4 Kepahiang (highland) students is better than that of SMA N 2 Kepahiang (lowland) students. With a difference rate of $13.32 \%$.

It happened because of many factors namely, differences in the nature of the climate that affect body shape, air pressure, oxygen levels, and lung volume capacity which causes the work function of the heart, lungs, and blood vessels to differ between highland and lowland areas. Students in highland areas have larger chest and lung circumferences and lower oxygen and air pressure levels, have higher lung volume and function capacities than students in lowland areas. In addition, hemoglobin levels in highland students are greater than in lowland areas, where it can bind more oxygen.

\section{REFERENCES}

[1] E. Sudirjo and M. N. Alif, Filsafat Pendidikan Jasmani, 1st ed. Sumedang Jawa Barat: UPI Sumedang Press, 2019. 
[2] R. Apriani and Nirwandi, "Perbandingan Tingkat Kebugaran Jasmani Siswa Putra Kelas XI IPA dengan Kelas XI IPS SMA Negeri 13 Pekanbaru," J. Pendidik. dan Olahraga, vol. 3, no. 10, pp. 33-40, 2020.

[3] M. I. Z. R. B. Endang Rini Sukamti, "Profil Kebugaran Jasmani Dan Status Kesehatan Instruktur Senam Aerobik Di Yogyakarta," J. Olahraga Prestasi, vol. 12, no. 2, p. 116313, 2016, doi: 10.21831/jorpres.v12i2.11875.

[4] F. Suharjana, "Kebugaran Kardiorespirasi dan Indek Masa Tubuh Mahasiswa KKN - PPL PGSD Penjas FIK UNY Kampus Wates," J. Pendidik. Jasm. Indones., vol. 9, pp. 119-120, 2013, doi: https://doi.org/10.21831/jpji.v9i2.3014.

[5] A. Yonsanny, M. Ismail, and H. Said, "Perancangan Augmented Reality Untuk Peta Topografi," Binus J. Publ., vol. 4, no. 2, p. 758, 2013, doi: https://doi.org/10.21512/comtech.v4i2.2587.

[6] R. E. Molenaar, J. J. V. Rampengan, and S. R. Marunduh, "Forced Expiratory Volume in One Second (Fev-1) Pada Penduduk Yang Tinggal Di Dataran Tinggi," J. e-Biomedik, vol. 2, no. 3, pp. 1-4, 2014, doi: 10.35790/ebm.2.3.2014.6200.

[7] G. Fitriady, "Perbandingan Validitas Tes VO2Max Antara Metode Maksimal dan Sub-Maksimal pada Remaja," Gelangg. Pendidik. Jasm. Indones., vol. 2, no. 2, pp. 116-119, 2018, doi: http://dx.doi.org/10.17977/um040v2i2p116-119.

[8] P. D. Sugiyono, Metode Penelitian Kuantitatif Kualitatif dan $R \& D$. Penerbit Alfabeta Bandung, 2013.

[9] Diklat Kemenpora, Kebugaran Jasmani. 2013.

[10] I. K. Sudiana, "Dampak Adaptasi Lingkungan terhadap Perubahan Fisiologis," in Seminar Nasional FMIPA UNDIKSHA 3, 2013, pp. 211-218.
[11] I. N. Sudarmada, "Perkembangan Kapasitas Vital Paru Anak Usia 6-12 Tahun," Media Ilmu Keolahragaan Indones., vol. 2, no. 1, 2012, doi: 10.15294/miki.v2i1.2553.

[12] R. Hariyono and S. C. Y. Hartati, "Perbandingan Tingkat Kebugaran Jasmani Siswa Kelas X Berdasarkan Letak Geografis (Studi Pada Siswa Putera Kelas X SMA Negeri 1 Ngadirojo Dan Siswa Putera Kelas X SMA Negeri 1 Tulakan)," J. Pendidik. Olahraga dan Kesehat., vol. 1, no. 2, pp. 318-324, 2013. 